\title{
Aktivitas Antibakteri Beberapa Tumbuhan Obat Hutan Etnis Kutai terhadap Streptococcus mutans dan Escherichia coli
}

\author{
Antibacterial Activity of Some Medicinal Forest Plants of Kutai Ethnic against \\ Streptococcus mutans and Escherichia coli
}

\begin{abstract}
Abdul Rasyid Zarta ${ }^{* 1}$, Fikri Hernandi ${ }^{2}$, Farida Aryani ${ }^{2}$, Joko Prayitno ${ }^{2}$, Rosalina Awing ${ }^{2}$
${ }^{1}$ Program Studi Rekayasa Kayu, Politeknik Pertanian Negeri Samarinda, Kalimantan Timur, Indonesia. ${ }^{2}$ Program Studi Pengolahan Hasil Hutan, Politeknik Pertanian Negeri Samarinda, Indonesia.

*Correspondence Author: zartapoltanesa@gmail.com
\end{abstract}

\begin{abstract}
ABSTRAK
Indonesia memiliki hutan tropis yang kaya akan beraneka ragam tumbuhan yang dapat digunakan sebagai obat tradisional, mulai dari akar, batang, daun, sampai buah semuanya mempunyai nilai yang besar dan dapat digunakan sebagai obat untuk kesehatan serta berasal dari berbagai suku yang berada di Indonesia. Senyawa antimikroba didefinisikan sebagai senyawa biologis atau kimia yang dapat menghambat pertumbuhan dan aktivitas mikroba. Tujuan dari penelitian ini adalah untuk mengetahui bioaktivitas anti bakteri ekstrak etanol $\left(\mathrm{C}_{2} \mathrm{H}_{6} \mathrm{O}\right)$ dari tiga jenis tumbuhan Pulutan (Urena lobata L), Kadamba (M. speciosa) dan Buah Ketitir (Brucea javanica L. Merr). terhadap bakteri Streptococcuss mutans dan Escherichia coli. Metode pengujian antibakteri dilakukan dengan metode difusi agar sumuran dengan modifikasi dengan menggunakan ekstrak etanol. Ekstrak etanol tumbuhan obat pulutan (Urena lobata L), kadamba (Mitragyna spesiosa), dan buah ketitir (Brucea javanica L. Merr) memberikan penghambatan lemah sampai dengan kuat terhadap pertumbuhan bakteri Escherichia coli dan Streptococcuss mutans. Konsentrasi ekstrak etanol 200 ( $\mu \mathrm{g} / \mathrm{well})$ memberikan penghambatan dengan klasifikasi kuat.
\end{abstract}

Kata kunci : antibakteri, ekstrak, penghambatan

\section{ABSTRACT}

Indonesia has tropical forests that are rich in a variety of plants that can be used as traditional medicine, ranging from roots, stems, leaves, until the fruits all have great value and can be used as medicine for health and come from various tribes in Indonesia. Antimicrobial compounds are defined as biological or chemical compounds that can inhibit microbial growth and activity. The purpose of this study was to determine of anti-bacterial bioactivity from ethanol extract $\left(\mathrm{C}_{2} \mathrm{H}_{5} \mathrm{OH}\right)$ from three types of plants pulutan (Urena lobata $L$ ), kadamba (Mitragyna speciosa) and ketitir fruit (Brucea javanica L. Merr). against Streptococcuss mutans and Escherichia coli bacteria. Antibacterial testing methods were carried out by diffusion method so that the wells were modified by using ethanol extract. Ethanol extract of pulutan medicinal plants (Urena lobata L), kadamba (Mitragyna spesiosa), and ketitir fruit (Brucea javanica L. Merr) gave a weak to strong inhibition of the growth of Escherichia coli bacteria and Streptococcuss mutans. The concentration of 200 ( $\mu \mathrm{g} / \mathrm{well})$ ethanol extract provides inhibition with a strong classification.

Keywords: antibacterial, extract, inhibition

\section{PENDAHULUAN}

Indonesia memiliki hutan tropis yang kaya akan beraneka ragam tumbuhan yang dapat digunakan sebagai obat tradisional, mulai dari akar, batang, daun, sampai buah semuanya mempunyai nilai yang besar dan dapat digunakan sebagai obat untuk kesehatan serta berasal dari berbagai suku yang berada di Indonesia. Setiap suku memiliki pengetahuan tentang pengobatan tradisional yang berbeda-beda (Septiyadi, 2005).

Khasiatnya diketahui dari penuturan orang-orang tua, tukar pikiran dengan anggota masyarakat lainnya dan hasil pengalaman sendiri. Pengetahuan ini bersifat turun-temurun yang disampaikan 
secara lisan dan umumnya diturunkan kepada turunannya atau anggota kelompoknya. Sejalan dengan gaya hidup moderen yang semakin terbuka dengan alternatif-alternatif lain yang tersedia, masyarakat lokal semakin kurang menggunakan tumbuhan liar. Namun, kemajuan ilmu pengetahuan dan teknologi ternyata tidak mampu begitu saja menghilangkan arti pengobatan tradisional.

Dewasa ini pengobatan dengan cara-cara tradisional semakin populer baik di dalam negeri maupun di luar negeri. Penggunaan tumbuhan obat secara tradisional semakin disukai karena umumnya tidak menimbulkan efek samping seperti halnya obat-obatan dari bahan kimia (Arisandi dan Yohana, 2006).

Senyawa antimikroba didefinisikan sebagai senyawa biologis atau kimia yang dapat menghambat pertumbuhan dan aktivitas mikroba. Senyawa antimikroba adalah jenis bahan tambahan pangan yang digunakan untuk tujuan mencegah kebusukan atau keracunan oleh mikroorganisme pada bahan pangan (Koswara, 2009).

Antimikroba alami dapat dinyatakan layak apabila memiliki efektifitas dalam menghambat mikroba perusak dan pathogen pangan serta memiliki ketersediaan yang melimpah. Apabila salah satu dari dua syarat tersebut tersebut tidak terpenuhi maka antimikroba alami tersebut dikatakan tidak layak (Syahidan, 2009).

Uji aktivitas anti bakteri digunakan untuk mengukur kemampuan suatu agen anti bakteri secara in vitro sehingga dapat menentukan potensi anti bakteri dalam larutan, konsentrasinya dalam cairan tubuh atau jaringan, dan kepekaan mikroorganisme penyebabnya terhadap obat yang digunakan untuk pengobatan (Jawetz et al, 2004).

Penelitian ini mengambil tumbuhan hutan yang dipergunakan sebagai obat tradisional yang telah dipergunakan oleh masyarakat di Desa Sebulu Moderen Kecamatan Sebulu, Kabupaten Kutai Kartanegara, Provinsi Kalimantan Timur, agar tumbuhan ini dapat terbukti secara ilmiah mengenai khasiatnya dan manfaatnya.

Tujuan dari penelitian ini adalah untuk mengetahui bioaktivitas anti bakteri ekstrak etanol $\left(\mathrm{C}_{2} \mathrm{H}_{6} \mathrm{O}\right)$ dari tiga jenis tumbuhan Pulutan (Urena lobata L), Kadamba (M. speciosa) dan Buah Ketitir (Brucea javanica L. Merr). terhadap bakteri Streptococcuss mutans dan Escherichia coli. Tumbuhan ini telah dipergunakan masyarakat setempat sebagai obat tradisional. Berdasarkan informasi masyarakat setempat jenis pulutan berkhasiat mengobati rematik dan luka, jenis kadamba berkhasiat untuk mengobati diabetes, malaria, jerawat, dan hepatitis serta Jenis buah ketitir berkhasiat melancarkan peredaran darah dan mengobati penyakit jantung.

\section{METODE PENELITIAN}

\section{Waktu dan Tempat Penelitian}

Penelitian ini dilaksanakan di Laboratorium Sifat Kayu dan Analisa Produk Program Studi Pengolahan Hasil Hutan Jurusan Teknologi Pertanian Politeknik Pertanian Negeri Samarinda. Waktu yang dibutuhkan dalam penelitian ini adalah 4 (empat) bulan.

\section{Bahan dan Alat}

Bahan baku yang digunakan pada penelitian ini adalah tumbuhan obat jenis Pulutan (Urena lobata L), Kadamba (M. speciosa) dan Buah Ketitir (Brucea javanica L. Merr) yang diambil dari Desa Sebulu Modern Kabupaten Kutai Kartanegara Provinsi Kalimantan Timur, Indonesia. Bagian tumbuhan yang digunakan adalah daun, kecuali jenis buah ketitir yang digunakan adalah buahnya yang meliputi kulit, daging dan biji buah.

Bahan lainnya yang digunakan agaragar (nutrijel), etanol $95 \% \quad\left(\mathrm{C}_{2} \mathrm{H}_{5} \mathrm{OH}\right)$, natrium broth $(\mathrm{NaCl})$, glukosa $\left(\mathrm{C}_{6} \mathrm{H}_{12} \mathrm{O}_{6}\right)$, aqudes $\left(\mathrm{H}_{2} \mathrm{O}\right)$, bakteri Streptococcus mutans dan bakteri Escherichia coli, aseton $\left(\mathrm{C}_{3} \mathrm{H}_{6} \mathrm{O}\right)$, chloramphenicol $\left(\mathrm{C}_{11} \mathrm{H}_{12} \mathrm{C}_{12} \mathrm{~N}_{2} \mathrm{O}_{5}\right)$, 3 (tiga) jenis ekstrak tumbuhan, aluminiumfoil, cling wrap, plastik, karung, parang, tisu, kertas label, sabun, spon, vaselin, kertas saring.

Alat penelitian yang digunakan yaitu blender, vacuum rotary evaporator, tabung reaksi, OSE, multikultur, erlenmeyer semua ukuran, beaker glass, cawan petri, spatula, 
oven, eppendorf microtub, timbangan analitik, baskom, glass, sonic, pit kecil dan besar, micropipet besar dan kecil, gunting, cutter, pinset, timbangan digital, autoclave, bor sumuran, laminar flow ESO, alat tulis menulis.

\section{Pembuatan Ekstrak Etanol Bahan}

Bahan baku berupa daun dan buah tumbuhan obat hutan yang telah diambil dicuci dan dikeringkan selama 3 (tiga) hari kemudian dihaluskan dengan menggunakan blender menjadi bentuk serbuk kasar. Serbuk yang diperoleh kemudian diekstraksi dengan menggunakan etanol selama 2x24 jam dan didapatkan ekstrak kasar.

\section{Pengujian Antibakteri}

Ekstrak kasar kemudian diujikan aktivitas penghambatan pada bakteri Streptococcus mutans dan Escherichia coli pada berbagai konsentrasi ekstrak yaitu 25 $\mu \mathrm{g} / \mathrm{well}, 50 \mu \mathrm{g} / \mathrm{well}, 100 \mu \mathrm{g} / \mathrm{well}$ dan 200 $\mu \mathrm{g} /$ well. Pengujian ini juga menggunakan kontrol positif yaitu Chloramphenicol $\left(\mathrm{C}_{11} \mathrm{H}_{12} \mathrm{C}_{12} \mathrm{~N}_{2} \mathrm{O}_{5}\right)$ dengan konsentrasi $\mu \mathrm{g} / \mathrm{well}$ dan control negatif yaitu aseton $\left(\mathrm{C}_{3} \mathrm{H}_{6} \mathrm{O}\right)$ dengan volume 20 mikroliter.

Metode pengujian antibakteri dilakukan dengan metode difusi agar sumuran yang mengacu pada metode Cappucino dan Sherman (2001) dengan modifikasi. Daya hambat ekstrak terhadap bakteri yang diuji diketahui dengan mengukur area penghambatan dengan menggunakan penggaris dalam satuan millimeter.

\section{Perhitungan dan Pengolahan Data}

Data hasil penelitian diperoleh dari hasil pengukuran lalu dihitung nilai ratarata dan aktivitas penghambatan relatifnya, kemudian ditabulasikan serta dianalisa dengan menggunakan grafik.

\section{HASIL DAN PEMBAHASAN}

\section{Profil Tumbuhan Obat Hutan}

Tumbuhan obat hutan yang dipergunakan dalam penelitian ini adalah 3 (tiga) jenis tumbuhan yang diambil dari lokasi hutan Desa Sebulu Modern, Kabupaten Kutai Kartanegara, Provinsi
Kalimantan Timur. Observasi telah dilakukan dan mendapatkan informasi dari masyarakat setempat mengenai pemanfaatan dan khasiat tumbuhan hutan yang dimanfaatkan secara tradisional untuk mengobati atau mencegah suatu penyakit dan menjaga kesehatan. Nama daerah yang disebutkan terhadap tumbuhan tersebut adalah jenis pulutan, kadamba dan buah ketitir.

Sampel daun tumbuhan tersebut divalidasi di Balai Penelitian dan Pengembangan Teknologi (Balitek), Samboja, Kutai Kartanegara hingga didapatkan nama ilmiah yaitu pulutan (Urena lobata L), kadamba (Mitragyna spesiosa), dan buah ketitir (Brucea javanica L. Merr).
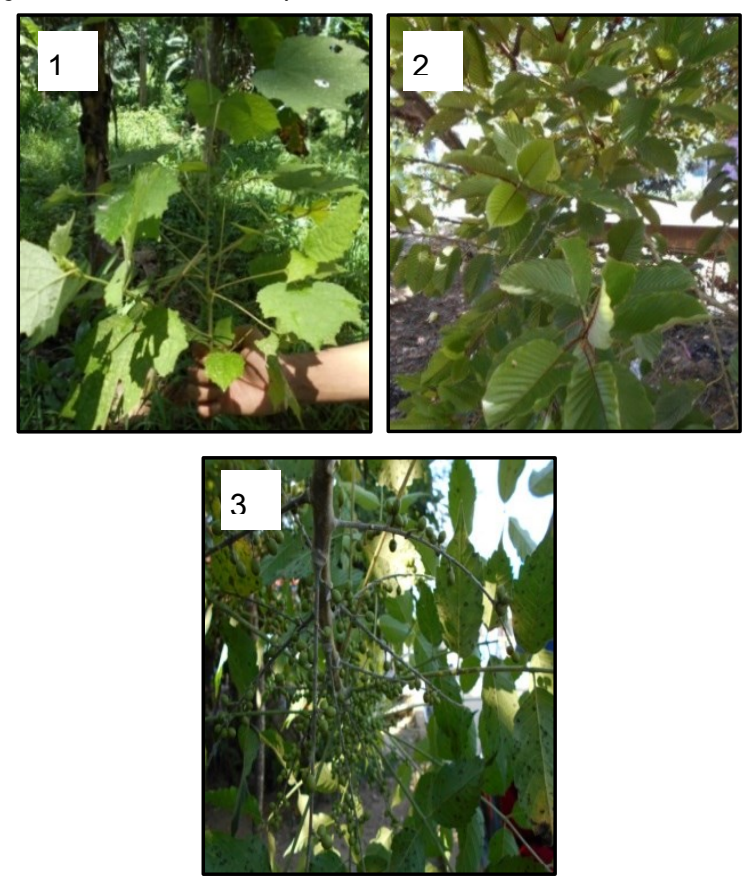

Gambar 1. Jenis Tumbuhan Obat Hutan ; (1) Pulutan (Urena lobata L), (2) Kadamba (Mitragyna spesiosa), (3) Buah Ketitir (Brucea javanica L. Merr).

Secara umum pemanfaatan bagian tumbuhan tersebut sebagai obat tradisional yaitu dengan direbus lalu diminum airnya. Informasi yang disampaikan oleh masyarakat setempat jenis pulutan berkhasiat mengobati rematik dan luka, jenis kadamba berkhasiat untuk mengobati diabetes, malaria, jerawat, dan hepatitis serta Jenis buah ketitir berkhasiat melancarkan peredaran darah dan mengobati penyakit jantung. Dibawah ini 
disampaikan gambar tumbuhan obat yang dipergunakan sebagai bahan baku pada penelitian ini.

\section{Penghambatan Ekstrak pada Bakteri Streptococcus mutans}

Aktivitas penghambatan bakteri Streptococcus mutans oleh ekstrak tumbuhan pulutan (Urena lobata L) dapat dilihat pada Tabel 1.

Berdasarkan tabel di atas terlihat bahwa masing-masing konsentrasi esktrak memiliki nilai penghambatan yang berbeda. Konsentrasi $25 \mu \mathrm{g} /$ well sebesar $7,55 \mathrm{~mm}$, konsentrasi $50 \mu \mathrm{g} /$ well sebesar $10,22 \mathrm{~mm}$, konsentrasi $100 \mu \mathrm{g} /$ well sebesar 10,44 mm dan konsentrasi $200 \mu \mathrm{g} /$ well sebesar 11 $\mathrm{mm}$. Semakin tinggi konsentrasi semakin meningkatkan kemampuan atau daya hambat terhadap bakteri Streptococcus mutans.

Klasifikasi Daya mengacu pada Ardiansyah (2005) yang mengklasifikasikan yaitu daya hambat lemah $(<5 \mathrm{~mm})$, sedang (5-10mm), kuat $(10-20 \mathrm{~mm})$ dan sangat kuat $(>20 \mathrm{~mm})$. Berdasarkan kalsifikasi tersebut bahwa hambatan terhadap bakteri dari ekstrak etanol daun pulutan adalah sedang sampai dengan kuat.

Berdasarkan data Tabel 1 diperlihatkan pula persentase nilai aktivitas penghambatan relatif ekstrak tumbuhan pulutan terhadap bakteri Streptococcus mutans yang secara grafis ditunjukkan pada gambar 2 .

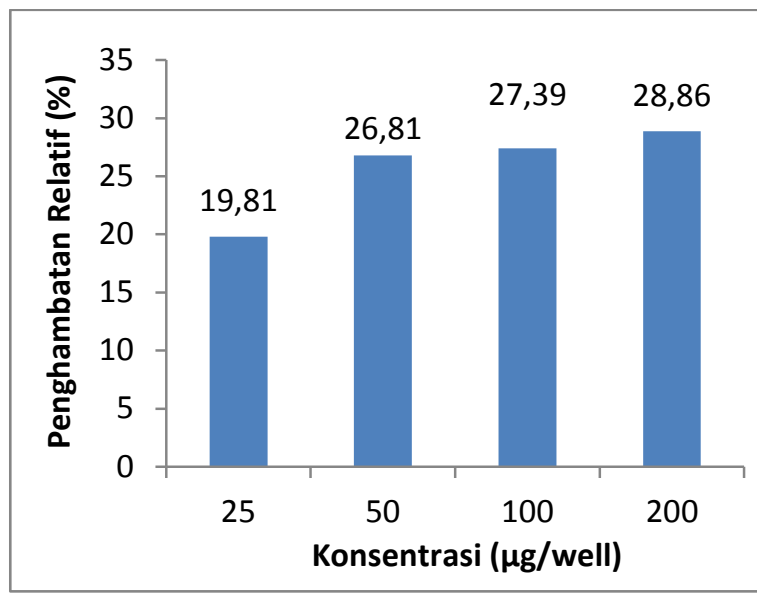

Gambar 2. Aktivitas Penghambatan Relatif Ekstrak Etanol Daun Pulutan (Urena lobata L) Pada Bakteri (Streptococcuss mutans)

Tabel 1. Penghambatan Bakteri Streptococcus mutans oleh Ekstrak Etanol Daun Pulutan (Urena lobata L)

\begin{tabular}{ccccccc}
\hline & & & \multicolumn{4}{c}{ Aktivitas Penghambatan $(\mathrm{mm})$} \\
\cline { 5 - 7 } & $\begin{array}{c}\text { Kontrol }(+) \\
(\mathrm{mm})\end{array}$ & $\begin{array}{c}\text { Kontrol }(-) \\
(\mathrm{mm})\end{array}$ & $\begin{array}{c}25 \\
(\mu \mathrm{g} / \mathrm{well})\end{array}$ & $\begin{array}{c}50 \\
(\mu \mathrm{g} / \mathrm{well})\end{array}$ & $\begin{array}{c}100 \\
(\mu \mathrm{g} / \mathrm{well})\end{array}$ & $\begin{array}{c}200 \\
(\mu \mathrm{g} / \mathrm{well})\end{array}$ \\
\hline Perhitungan 1 & 38,33 & 0,00 & 10,66 & 10,66 & 10,66 & 11,00 \\
Perhitungan 2 & 38,00 & 0,00 & 6,00 & 10,00 & 10,33 & 11,00 \\
Perhitungan 3 & 38,00 & 0,00 & 6,00 & 10,00 & 10,33 & 11,00 \\
\hline Rata - Rata & 38,11 & 0,00 & 7,55 & 10,22 & 10,44 & 11,00 \\
\hline Koefisien & 0,50 & 0,00 & 35,62 & 3,73 & 1,82 & 0,00 \\
Variasi (\%) & & & & &
\end{tabular}

Tabel 2. Penghambatan Bakteri Streptococcus mutans oleh Ekstrak Etanol Tumbuhan Kadamba (Mitragyna speciosa)

\begin{tabular}{ccccccc}
\hline & & & \multicolumn{4}{c}{ Aktivitas Penghambatan $(\mathrm{mm})$} \\
\cline { 4 - 7 } & $\begin{array}{c}\text { Kontrol }(+) \\
(\mathrm{mm})\end{array}$ & $\begin{array}{c}\text { Kontrol }(-) \\
(\mathrm{mm})\end{array}$ & $\begin{array}{c}25 \\
(\mu \mathrm{g} / \mathrm{well})\end{array}$ & $\begin{array}{c}50 \\
(\mu \mathrm{g} / \mathrm{well})\end{array}$ & $\begin{array}{c}100 \\
(\mu \mathrm{g} / \mathrm{well})\end{array}$ & $\begin{array}{c}200 \\
(\mu \mathrm{g} / \mathrm{well})\end{array}$ \\
\hline Perhitungan 1 & 40,00 & 0,00 & 9,00 & 10,33 & 13,00 & 13,66 \\
Perhitungan 2 & 41,00 & 0,00 & 0,00 & 9,00 & 11,33 & 12 \\
Perhitungan 3 & 40,33 & 0,00 & 8,66 & 11,33 & 11,66 & 12,66 \\
\hline Rata - Rata & 40,44 & 0,00 & 5,88 & 10,22 & 11,99 & 12,77 \\
\hline Koefisien & 1,26 & 0,00 & 86,65 & 11,44 & 7,37 & 6,54 \\
\hline Variasi $(\%)$ & & & & & & \\
\hline
\end{tabular}


Tabel 3. Penghambatan Bakteri Streptococcus mutans oleh Ekstrak Etanol Buah ketitir (Brucea javanica L. Merr)

\begin{tabular}{|c|c|c|c|c|c|c|}
\hline & \multirow[b]{2}{*}{$\begin{array}{c}\text { Kontrol }(+) \\
(\mathrm{mm})\end{array}$} & \multirow[b]{2}{*}{$\begin{array}{c}\text { Kontrol (-) } \\
(\mathrm{mm})\end{array}$} & \multicolumn{4}{|c|}{ Aktivitas Penghambatan (mm) } \\
\hline & & & $\begin{array}{c}25 \\
(\mu \mathrm{g} / \text { well) } \\
\end{array}$ & $\begin{array}{c}50 \\
(\mu \mathrm{g} / \text { well })\end{array}$ & $\begin{array}{c}100 \\
(\mu \mathrm{g} / \text { well })\end{array}$ & $\begin{array}{c}200 \\
(\mu \mathrm{g} / \mathrm{well})\end{array}$ \\
\hline Perhitungan 1 & 40,33 & 0,00 & 0,00 & 0,00 & 0,00 & 10,33 \\
\hline Perhitungan 2 & 43,33 & 0,00 & 0,00 & 0,00 & 0,00 & 11,33 \\
\hline Perhitungan 3 & 40,00 & 0,00 & 0,00 & 8,66 & 10,33 & 10,66 \\
\hline Rata - Rata & 41,22 & 0,00 & 0,00 & 2,88 & 3,44 & 10,77 \\
\hline $\begin{array}{c}\text { Koefisien } \\
\text { Variasi }(\%)\end{array}$ & 4,45 & 0,00 & 0,00 & 173,21 & 173,21 & 4,73 \\
\hline
\end{tabular}

Aktivitas penghambatan bakteri Streptococcus mutans oleh ekstrak tumbuhan kadamba (Mitragyna speciosa) dapat dilihat pada Tabel 2. Dari Tabel 2 di atas terlihat bahwa masing-masing konsentrasi esktrak memiliki nilai penghambatan yang berbeda. Konsentrasi $25 \mu \mathrm{g} /$ well sebesar $5,88 \mathrm{~mm}$, konsentrasi $50 \mu \mathrm{g} /$ well sebesar $10,22 \mathrm{~mm}$, konsentrasi $100 \mu \mathrm{g} /$ well sebesar $11,99 \mathrm{~mm}$ dan konsentrasi $200 \mu \mathrm{g} /$ well sebesar 12,77 $\mathrm{mm}$. Klasifikasi hambatan dari ekstrak etanol daun kadamba adalah lemah sampai dengan kuat.

Berdasarkan Tabel 2 terlihat pula persentase nilai aktivitas penghambatan relatif dari ekstrak tumbuhan kadamba (Mitragyna speciosa) terhadap bakteri Streptococcus mutan yang secara grafis disajikan pada Gambar 3.

Selanjutnya aktivitas penghambatan bakteri Streptococcus mutans oleh ekstrak tumbuhan buah ketitir (Brucea javanica L. Merr) ditampilkan pada Tabel 3.

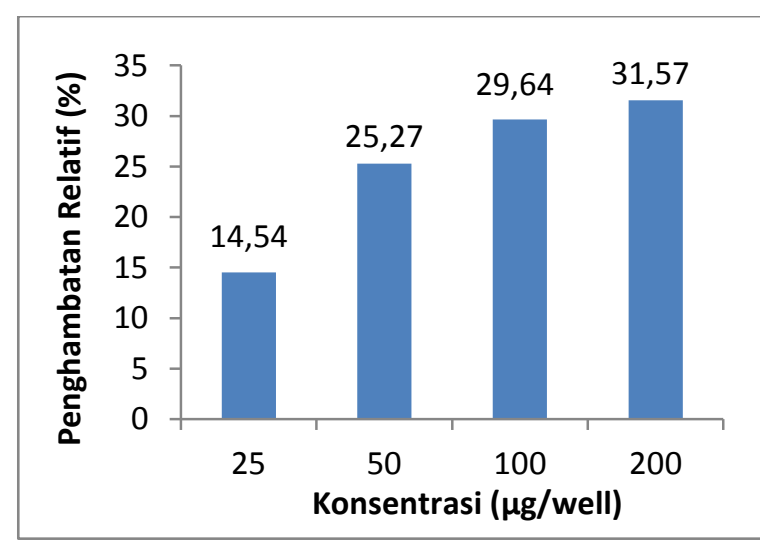

Gambar 3. Aktivitas Penghambatan Relatif Ekstrak Etanol Daun Kadamba (Mitragyna speciosa) terhadap Bakteri Streptococcus mutans
Pada Tabel 3 di atas terlihat bahwa masing-masing konsentrasi esktrak memiliki nilai penghambatan yang berbeda pula. Konsentrasi $25 \mu \mathrm{g} /$ well tidak memiliki hambatan, konsentrasi $50 \mu \mathrm{g} /$ well sebesar 2,88mm, konsentrasi $100 \mu \mathrm{g} /$ well sebesar $3,44 \mathrm{~mm}$ dan konsentrasi $200 \mu \mathrm{g} /$ well sebesar $10,77 \mathrm{~mm}$. Klasifikasi hambatan dari ekstrak etanol buah ketitir adalah lemah sampai dengan kuat.

Berdasarkan data pada Tabel 3 diketahui juga persentase nilai aktivitas penghambatan relatif dari Tumbuhan Buah Ketitir (Brucea javanica L. Merr) pada Bakteri (Streptococcus mutans) yang ditampilkan pada gambar di bawah ini :

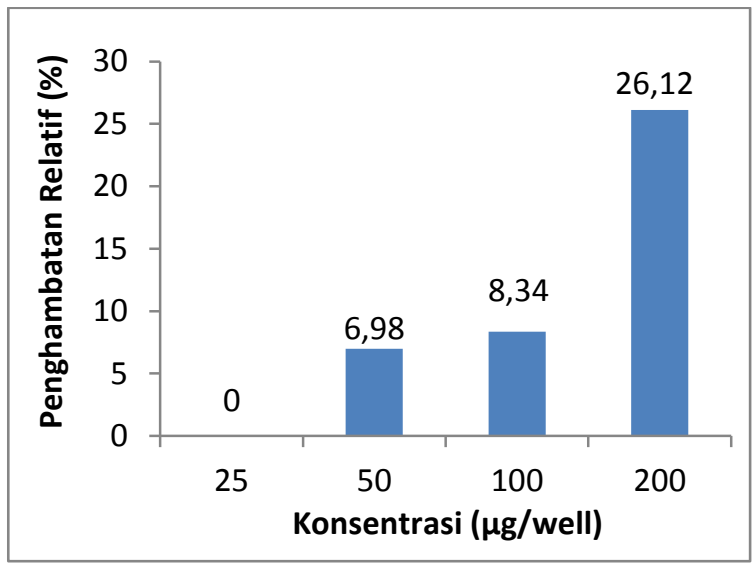

Gambar 4. Aktivitas Penghambatan Relatif Ekstrak Etanol Buah Ketitir (Brucea javanica L. Merr) Pada Bakteri Streptococcus mutans

\section{Penghambatan Ekstrak pada Bakteri Escherichia coli}

Aktivitas penghambatan bakteri Escherichia coli oleh ekstrak tumbuhan pulutan (Urena lobata L) disajikan pada Tabel 4 di bawah ini : 
Tabel 4. Penghambatan Bakteri Escherichia coli oleh Ekstrak Etanol Daun Pulutan (Urena lobata L)

\begin{tabular}{ccccccc}
\hline & & \multicolumn{4}{c}{ Aktivitas Penghambatan $(\mathrm{mm})$} \\
\cline { 4 - 7 } & $\begin{array}{c}\text { Kontrol }(+) \\
(\mathrm{mm})\end{array}$ & $\begin{array}{c}\text { Kontrol }(-) \\
(\mathrm{mm})\end{array}$ & $\begin{array}{c}25 \\
(\mu \mathrm{g} / \text { well })\end{array}$ & $\begin{array}{c}50 \\
(\mu \mathrm{g} / \mathrm{well})\end{array}$ & $\begin{array}{c}100 \\
(\mu \mathrm{g} / \mathrm{well})\end{array}$ & $\begin{array}{c}200 \\
(\mu \mathrm{g} / \mathrm{well})\end{array}$ \\
\hline Perhitungan 1 & 27,66 & 0,00 & 0,00 & 0,00 & 0,00 & 10,33 \\
Perhitungan 2 & 27,66 & 0,00 & 0,00 & 9,66 & 10,00 & 12,00 \\
Perhitungan 3 & 26,33 & 0,00 & 0,00 & 10,33 & 11,33 & 13,33 \\
\hline Rata - Rata & 27,21 & 0,00 & 0,00 & 6,66 & 7,11 & 11,88 \\
\hline Koefisien & 2,82 & 0,00 & 0,00 & 86,75 & 87,11 & 12,65 \\
Variasi (\%) & & & & & & \\
\hline
\end{tabular}

Tabel 5. Penghambatan Bakteri Escherichia coli oleh Ekstrak Etanol Daun kadamba (Mitragyna spesiosa)

\begin{tabular}{ccccccc}
\hline & & & \multicolumn{4}{c}{ Aktivitas Penghambatan $(\mathrm{mm})$} \\
\cline { 4 - 7 } & $\begin{array}{c}\text { Kontrol }(+) \\
(\mathrm{mm})\end{array}$ & $\begin{array}{c}\text { Kontrol }(-) \\
(\mathrm{mm})\end{array}$ & $\begin{array}{c}25 \\
(\mu \mathrm{g} / \text { well })\end{array}$ & $\begin{array}{c}50 \\
(\mu \mathrm{g} / \text { well })\end{array}$ & $\begin{array}{c}100 \\
(\mu \mathrm{g} / \mathrm{well})\end{array}$ & $\begin{array}{c}200 \\
(\mu \mathrm{g} / \mathrm{well})\end{array}$ \\
\hline Perhitungan 1 & 38,33 & 0,00 & 8,66 & 10,00 & 10,33 & 11,00 \\
Perhitungan 2 & 29,00 & 0,00 & 9,66 & 10,33 & 11,66 & 12,66 \\
Perhitungan 3 & 25,33 & 0,00 & 9,00 & 9,66 & 10,33 & 11,33 \\
\hline Rata - Rata & 27,55 & 0,00 & 9,10 & 9,99 & 10,77 & 11,66 \\
\hline Koefisien & 21,70 & 0,00 & 5,58 & 3,35 & 7,13 & 7,53 \\
Variasi (\%) & & & & & &
\end{tabular}

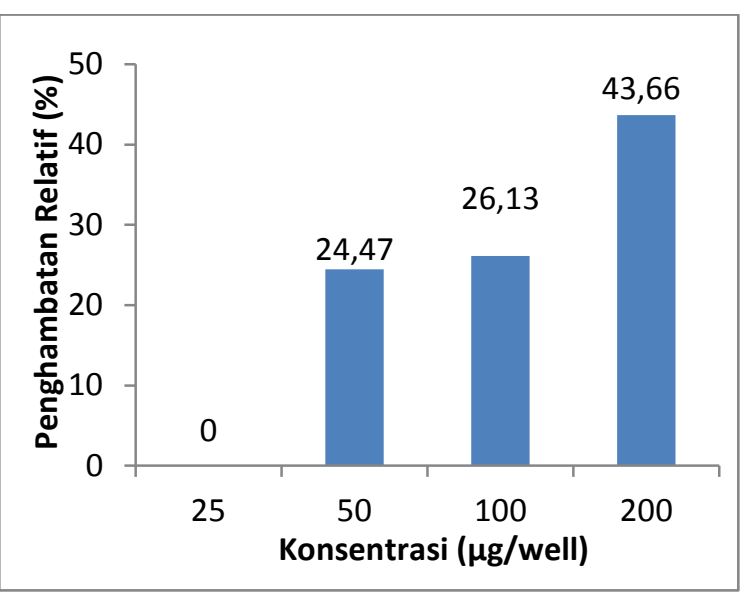

Gambar 5. Aktivitas Penghambatan Relatif Ekstrak Etanol Daun Pulutan (Urena lobata L) Pada Bakteri Escherichia coli

Pada Tabel 4 terlihat bahwa masingmasing konsentrasi esktrak memiliki nilai penghambatan yang berbeda. Konsentrasi $25 \mu \mathrm{g} /$ well tidak mempunyai daya hambat atau sebesar $0,00 \mathrm{~mm}$, konsentrasi 50 $\mu \mathrm{g} /$ well sebesar $6,66 \mathrm{~mm}$, konsentrasi 100 $\mu \mathrm{g} /$ well sebesar $7,11 \mathrm{~mm}$ dan konsentrasi $200 \mu \mathrm{g} /$ well sebesar $11,88 \mathrm{~mm}$. Semakin tinggi konsentrasi semakin meningkatkan kemampuan atau daya hambat terhadap bakteri Streptococcus mutans.

Berdasarkan data Tabel 4 diperlihatkan pula persentase nilai aktivitas penghambatan relatif ekstrak tumbuhan pulutan terhadap bakteri Escherichia coli yang secara grafis ditunjukkan pada Gambar 5.

Pada Tabel 5 terlihat bahwa masingmasing konsentrasi esktrak memiliki nilai penghambatan yang berbeda. Konsentrasi $25 \mu \mathrm{g} /$ well mempunyai daya hambat sebesar $9,10 \mathrm{~mm}$, konsentrasi $50 \mu \mathrm{g} /$ well sebesar 9,99 mm, konsentrasi $100 \mu \mathrm{g} /$ well sebesar 10,77 mm dan konsentrasi 200 $\mu \mathrm{g} /$ well sebesar $11,66 \mathrm{~mm}$. Semakin tinggi konsentrasi semakin meningkatkan kemampuan atau daya hambat terhadap bakteri Streptococcus mutans.

Berdasarkan data Tabel 5 diperlihatkan pula persentase nilai aktivitas penghambatan relatif ekstrak daun kadamba terhadap bakteri Escherichia coli yang secara grafis ditunjukkan pada Gambar 6. 
Tabel 6. Penghambatan Bakteri Escherichia coli oleh Ekstrak Etanol Buah Ketitir (Brucea javanica L. Mer)

\begin{tabular}{ccccccc}
\hline & & & \multicolumn{4}{c}{ Aktivitas Penghambatan $(\mathrm{mm})$} \\
\cline { 4 - 7 } & $\begin{array}{c}\text { Kontrol }(+) \\
(\mathrm{mm})\end{array}$ & $\begin{array}{c}\text { Kontrol }(-) \\
(\mathrm{mm})\end{array}$ & $\begin{array}{c}25 \\
(\mu \mathrm{g} / \text { well })\end{array}$ & $\begin{array}{c}50 \\
(\mu \mathrm{g} / \text { well })\end{array}$ & $\begin{array}{c}100 \\
(\mu \mathrm{g} / \mathrm{well})\end{array}$ & $\begin{array}{c}200 \\
(\mu \mathrm{g} / \mathrm{well})\end{array}$ \\
\hline Perhitungan 1 & 27,00 & 0,00 & 0,00 & 9,00 & 9,33 & 10,00 \\
Perhitungan 2 & 29,33 & 0,00 & 0,00 & 0,00 & 0,00 & 9,66 \\
Perhitungan 3 & 26,66 & 0,00 & 0,00 & 0,00 & 0,00 & 9,33 \\
\hline Rata - Rata & 27,66 & 0,00 & 0,00 & 3,00 & 3,11 & 9,66 \\
\hline Koefisien & 5,25 & 0,00 & 0,00 & 173,21 & 173,21 & 3,47 \\
\hline Variasi (\%) & & & & & &
\end{tabular}

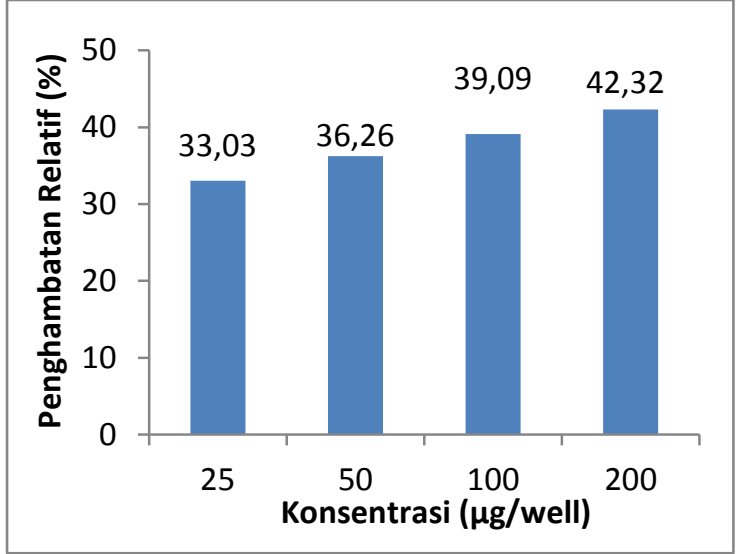

Gambar 6. Aktivitas Penghambatan Relatif Ekstrak Etanol Daun Kadamba (Mitragyna spesiosa) Pada Bakteri Escherichia coli

Aktivitas penghambatan bakteri Escherichia coli oleh ekstrak buah ketitir (Brucea javanica L. Mer) disajikan pada Tabel 6 di atas. Berdasarkan data Tabel 6 diperlihatkan pula persentase nilai aktivitas penghambatan relatif ekstrak buah ketitir terhadap bakteri Escherichia coli yang secara grafis ditunjukkan pada Gambar 7.

Berdasarkan klasifikasi daya hambat bakteri yang dikemukakan oleh Ardiansyah (2005) bahwa secara umum hasil penelitian ini menunjukkan bahwa tiga jenis tumbuhan yaitu ekstrak daun pulutan (Urena lobata. L), kadamba (Mitragyna speciosa), buah ketitir (Brucea javanica L. Merr) memberikan penghambatan yang bervariasi mulai dari lemah sampai dengan kuat terhadap bakteri Streptococcus mutans dan Escherichia coli.

Pada gambar grafik di atas terlihat bahwa semakin tinggi konsentrasi ekstrak

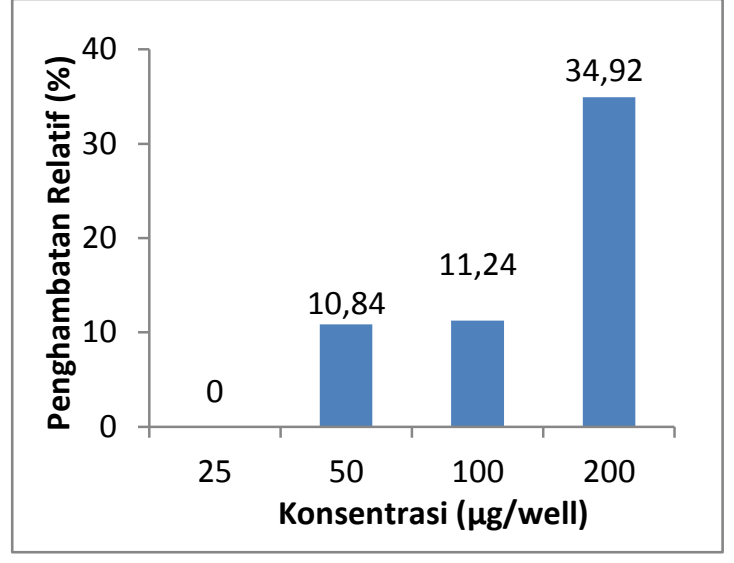

Gambar 7. Aktivitas Penghambatan Relatif Ekstrak Etanol Buah Ketitir (Brucea javanica) Pada Bakteri Escherichia coli

maka semakin meningkatkan kekuatan daya hambat ekstrak terhadap perkembangan bakteri. Kondisi ini diperkuat oleh dengan penjelasan yang disampaikan oleh Dwidjoseputro (2003) yang menyatakan bahwa semakin rendah konsentrasi dari antibiotik maka daya hambatnya akan semakin lemah sehingga zona yang terbentuk akan semakin kecil dan sebaliknya semakin tinggi konsentrasi antibotik, maka semakin besar zona bening yang terbentuk. Diperkuat pula oleh Prawata dan Dewi, (2008) bahwa semakin tinggi konsentrasi zat suatu bahan anti bakteri maka aktivitas anti bakterinya semakin kuat.

Dari penelitian juga terlihat adanya ekstrak etanol tumbuhan yang tidak memiliki daya hambat terhadap perkembangan bakteri. Tidak adanya hambatan terhadap bakteri dapat disebabkan oleh beberapa hal, namun yang paling utama adalah konsentrasi 
ekstrak yang sedikit sehingga tidak dapat menghambat pertumbuhan bakteri, Sebagaimana dijelaskan oleh Brooks et al (2013) menyatakan bahwa aktivitas anti bakteri dipengaruhi oleh beberapa faktor, yaitu konsentrasi ekstrak, kandungan senyawa anti bakteri, daya difusi ekstrak dan jenis bakteri yang dihambat.

Sebab lainnya dapat juga terjadi sebagaimana penjelasan oleh Pramuningtyas, dkk. (2009) yang menyatakan bahwa tidak adanya hambatan sama sekali pada bakteri Escherichia coli dan Streptococcuss mutans dimungkinkan karena berbagai kandungan kimia dari ekstrak sebagian besar ikut terambil.

\section{KESIMPULAN}

Berdasarkan hasil penelitian diperoleh kesimpulan bahwa ekstrak tumbuhan obat pulutan (Urena lobata L), kadamba (Mitragyna spesiosa), dan buah ketitir (Brucea javanica L. Merr) memberikan penghambatan lemah sampai dengan kuat terhadap pertumbuhan bakteri Escherichia coli dan Streptococcuss mutans. Konsentrasi ekstrak etanol 200 ( $\mu \mathrm{g} /$ well) memberikan penghambatan dengan klasifikasi kuat.

\section{DAFTAR PUSTAKA}

Ardiansyah. 2005. Daun beluntas sebagai bahan antibakteri dan antioksidan. Artikel. IPTEK- Bidang Biology, Pangan dan Kesehatan.

Arisandi dan Yohana. 2006. Khasiat Tanaman Obat. 40, 49, 254, 281, Pustaka buku murah : Jakarta.

Brooks, GF., Carroll KC, Butel JS, Morse, 2013. Mikrobiologi Kedokteran Jawetz, Melnick, \& adelberg. Ed. 25. Penerbit Buku Kedokteran EGC: Jakarta.

Cappucino J.G., and N. Sherman, 2001. Microbiology: A Laboratory Manual. 2nd Edition. The Benjamin Cummings Publishing Company. Rockland Community College. State University of New York

Dwidjoseputro, D. 2003. Dasar-dasar Mikrobiologi. Djambatan. Jakarta.
Jawetz, Melnick, dan Adelbergs, 2004. Mikrobiologi Kedokteran, Ed 23, Penerbit Buku Kedokteran EGC, Jakarta, page 233, 235.

Koswara S., 2009. Pengawet Alami Untuk Produk Dan Bahan Pangan. eBookPangan.com

Pramuningtyas, Ratih. dan Rahadian. 2009 W.B., Uji Aktifitas Antimikroba Ekstrak Etanol Daun Cocor Bebek (Kalanchoe Pinnata) terhadap Bakteri Staphylococcus aureus Attc 6538 dan Escherichia coli Atcc 11229 Secara Invitro. Biomedika. I (2): 43-50.

Prawata I. M. O. K \& Dewi P. S. F., 2008, Isolasi Dan Uji Aktivitas Antibakteri Minyak Atsiri Dan Rimpang Lengkuas (Alpinia galangal L.), Jurnal Kimia, 2 (2): 100-104.

Septiyadi. E., 2005. Pengobatan Alternatif Alamiah Melalui Tumbuh- Tumbuhan. 1, 2, 3. Restu Agung :Jakarta.

Syahidan A.M., 2009. Kajian Hasil Riset Antimikroba Alami pada Bahan Pangan Hewani. Skripsi pada Fakultas Teknologi Pertanian, IPB, Bogor. 